\title{
Deltins: immunochemical evidence for a novel population of peptides of the $D$ cells of the gastro-entero-pancreatic endocrine system
}

\author{
R Lomský, J Príbyšová, V Jirkalová and F Saudek ${ }^{\mathbf{1}}$ \\ Centre for Protein and Peptide Hormones, Charles University in Prague, Faculty of Medicine in Hradec Králové, University Hospital, \\ Hradec Králové, Czech Republic \\ ${ }^{1}$ Islet Cell Laboratory, Diabetes Centre, Institute of Clinical and Experimental Medicine, Prague, Czech Republic \\ (Requests for offprints should be addressed to R Lomský, Centre for Protein and Peptide Hormones, University Hospital, \\ 50005 Hradec Králové, Czech Republic)
}

\begin{abstract}
Differences between the immunocytochemical behaviour of antisera to partially purified porcine gastrins and antisera to either synthetic human gastrin-17-I or highly purified porcine gastrin-17-I raised the hypothesis that hog antral gastrin extracts contain peptides different from somatostatin and gastrin that are responsible for the immunocytochemical reaction of the former antisera in the D (delta) cells of the gastro-entero-pancreatic (GEP) endocrine system. This study was performed to prove this hypothesis. A discard fraction obtained after gel filtration of hog antral gastrin extracts on Sephadex G-50 Superfine was employed to immunize five rabbits. The discard fraction is highly heterogeneous on two-dimensional electrophoresis and contains merely traces of somatostatin and gastrin in RIA. However, rabbit antisera to the discard fraction give strongly positive immunocytochemical reactions exclusively in the $\mathrm{D}$ cells of the human antroduodenal mucosa and of the pancreatic islets. Absorption
\end{abstract}

of the antisera with the lyophilized discard fraction abolishes the staining of the $\mathrm{D}$ cells, whereas absorption of the antisera with several somatostatins does not affect the staining. Vice versa, staining of the $\mathrm{D}$ cells with antisera to cyclic somatostatin-14 is abolished by absorption of the antisera with somatostatin-14 but not by absorption with excess of the discard fraction. In RIA, antisera to the discard fraction do not bind radiolabelled $\left(\mathrm{Tyr}^{1}{ }^{1}\right)-$ somatostatin-14, Tyr-somatostatin-28 or synthetic human gastrin-17-I. Two-dimensional electrophoresis of acid extracts of isolated canine pancreatic islets followed by Western blotting shows different patterns of distribution of immunoreactive spots obtained with antisera to the discard fraction, to somatostatin-14, and to human proinsulin respectively. These results indicate the existence of a novel population of peptides of the $\mathrm{D}$ cells of the GEP endocrine system, for which we propose the term deltins.

Journal of Endocrinology (2001) 168, 391-400

\section{Introduction}

The existence of gastrin in islet cell tumours of the pancreas associated with the Zollinger-Ellison syndrome led to the search for gastrin in the normal islets. A number of studies demonstrated immunoreactivity of pancreatic D (delta) cells with antisera raised against gastrin (Lomský et al. 1969, Greider \& McGuigan 1971, Polak et al. 1972, Vassallo et al. 1972, Erlandsen et al. 1976). There are, however, differences between the results obtained with antisera to synthetic human gastrin I, which displayed immunoreactivity only in cryostat-cut sections of human pancreatic tissue (Greider \& McGuigan 1971, Polak et al. 1972, Vassallo et al. 1972), and with antisera to porcine gastrin prepared from antral mucosa, which showed positive immunocytochemical reactions in the $\mathrm{D}$ cells of the islets in paraffin-embedded sections after fixation of pancreatic specimens with formalin or Bouin's fluid (Lomský et al. 1969, Erlandsen et al. 1976).

The presence of gastrin in the human islets was seriously questioned by a number of authors (Creutzfeldt 1975, Creutzfeldt et al. 1971, Lotstra et al. 1974, Larsson et al. 1975, Alumets et al. 1977), who did not find any immunoreactivity of the D cells with antisera to synthetic human gastrin I. Controversial results were obtained also using RIA of gastrin in extracts of the human pancreas (Creutzfeldt et al. 1971, Greiger \& McGuigan 1971, Nilsson et al. 1973, Alumets et al. 1977). An unequivocal evidence for the presence of gastrin in the islets was found in rodents (Braaten et al. 1974, 1976, Larsson et al. 1976, Dockray et al. 1977). In addition, Larsson et al. (1976) demonstrated the fact that not the D cells, but the $G$ cells of the normal islets, if present in the given species, are responsible for the production of pancreatic gastrin. 
Following isolation of somatostatin from the hypothalamus (Brazeau et al. 1973), somatostatin-like immunoreactivity was detected immunocytochemically in the D cells of the gastro-entero-pancreatic (GEP) endocrine system (Luft et al. 1974, Dubois 1975, Hökfelt et al. 1975, Orci et al. 1975, Polak et al. 1975, Rufener et al. 1975) and somatostatin became an established peptide hormone of the pancreatic islets. However, the positive immunocytochemical reactions of antisera to porcine gastrin prepared from antral mucosa in the D cells of formalin-fixed, paraffin-embedded pancreatic tissue (Lomský et al. 1969, Erlandsen et al. 1976) remained unexplained. The objective of the present paper is to provide evidence that hog antral gastrin extracts contain, in addition to gastrin, a novel population of peptides, for which we propose the term deltins, because the antisera to these peptides display immunocytochemical reactions exclusively in the D (delta) cells of the GEP endocrine system and the peptides are different immunochemically from the populations of somatostatins and gastrins. It is assumed that the positive immunocytochemical reactions obtained with antisera to porcine gastrin in the $\mathrm{D}$ cells of the pancreatic islets (Lomský et al. 1969, Erlandsen et al. 1976) were due to the presence of deltins in gastrin preparations used in immunizations.

\section{Materials and Methods}

\section{Materials}

Sephadex G-50 Superfine, Sephadex G-25 Fine and Medium, DEAE Sepharose Fast Flow, protein A-Sepharose CL-4B, Immobiline DryStrips, $\mathrm{pH}$ 3-10 $\mathrm{NL}, 18 \mathrm{~cm}$, and $\mathrm{pH} 4-7,18 \mathrm{~cm}$, acrylamide, bromophenol blue and the low molecular weight (LMW) electrophoresis calibration kit were from Pharmacia Biotech (Uppsala, Sweden). Carrier ampholytes Resolyte $\mathrm{pH} 4-8$ was from $\mathrm{BDH}$ (Poole, UK). Paraffin highly liquid and glycerol were from Merck (Darmstadt, Germany). Dithiothreitol (DTT), iodoacetamide, piperazindiacrylamide (PDA), glycine, 3-[(3-cholamidopropyl)dimethylammonio]-1propane-sulphonate (CHAPS), ammonium persulphate (APS), sodium dodecyl sulphate (SDS) and Tris were from Fluka (Buchs, Switzerland). N,N,N',N'-tetramethylethylenediamine (TEMED) and agarose were from Serva (Heidelberg, Germany). Aminoethylcellulose (AE-11) was from Whatman (Maidstone, UK). Polyvinylidene fluoride (PVDF) sheets (Immobilon-P) were obtained from Millipore (Bedford, MA, USA). Fluorescein isothiocyanate, isomer I (FITC), was from the Research Institute of Pharmacy and Biochemistry (Prague, Czech Republic). Succinimidyl-7-amino-4-methyl-coumarin-3-acetic acid (AMCA-NHS), 1-ethyl-3-(3-dimethyl-aminopropyl) carbodiimide hydrochloride and phenylisothiocyanate were from Pierce (Rockford, IL, USA). 3,3'-diaminobenzidine tetrahydrochloride (DAB), newborn calf serum,
Ficoll 400 DL were from Sigma (St Louis, MO, USA). Al-Span-Oil adjuvant mixture was from Sevac (Prague, Czech Republic). All other chemicals were of the purest grade available commercially.

\section{Peptides and proteins}

Synthetic human gastrin-17-I (SHG I), cyclic somatostatin-14, somatostatin-25, somatostatin-28, Tyrsomatostatin-28, human $\beta$-endorphin, BSA and horseradish peroxidase (HRP), type VI-A (RZ approx 3.0), were purchased from Sigma. In addition, cyclic somatostatin-14, somatostatin-28, somatostatin-28 (1-12), somatostatin-28 (1-14) and $\left(\mathrm{Tyr}^{1}\right)$-somatostatin-14 were obtained from Bachem (Torrance, CA, USA). (5Leucine)-enkephalin and (5-methionine)-enkephalin were obtained from Fluka. Recombinant human proinsulin was a gift from Eli Lilly and Co. (Indianapolis, IN, USA).

Porcine non-sulphated gastrin-17-I (LG I = little gastrin I) and sulphated gastrin-17-II (LG II=little gastrin II) were isolated from hog antral mucosa by the method of Gregory \& Tracy (1964). The antral gastrin extract was applied to a column of Sephadex G-50 Superfine $(4.5 \times 67 \mathrm{~cm})$ packed in $40 \mathrm{mmol} / 1$ ammonium bicarbonate and the column was run at a flow rate of $5 \mathrm{ml}$ per $15 \mathrm{~min}$ (Fig. 1). The elution profile was divided into several fractions and the contents of the tubes in the particular fractions were pooled and lyophilized. Radioimmunoassay of somatostatin and gastrin both in the eluate and in the lyophilized materials was performed as described below. Table 1 indicates the concentrations of somatostatin (expressed as equivalents of cyclic somatostatin-14) and gastrin (expressed as equivalents of SHG I) per mg dry weight found in the lyophilized materials from the individual chromatographic fractions. Materials from the two gastrin peaks were chromatographed on a column of aminoethylcellulose. The central portions of each of the two gastrin peaks were lyophilized and rechromatographed on aminoethylcellulose using gentler gradients of ammonium bicarbonate concentrations as described by Gregory \& Tracy (1964). The central portions of each of the gastrin peaks were pooled and lyophilized.

Staphylococcic protein A was a product of Pharmacia Biotech. Collagenase was obtained from Sevac.

\section{Deltin fraction}

The lyophilized material from the first of the discard fractions obtained after gel filtration of the Gregory-Tracy hog antral gastrin extract on a column of Sephadex G-50 Superfine (tubes $72-87$ in Fig. 1) was used to immunize five rabbits. The material was found to be highly heterogeneous on 2-D PAGE (Fig. 2). The fraction contains only traces of somatostatin $(1 \cdot 1 \mathrm{ng} / \mathrm{mg}$ dry weight) and gastrin 


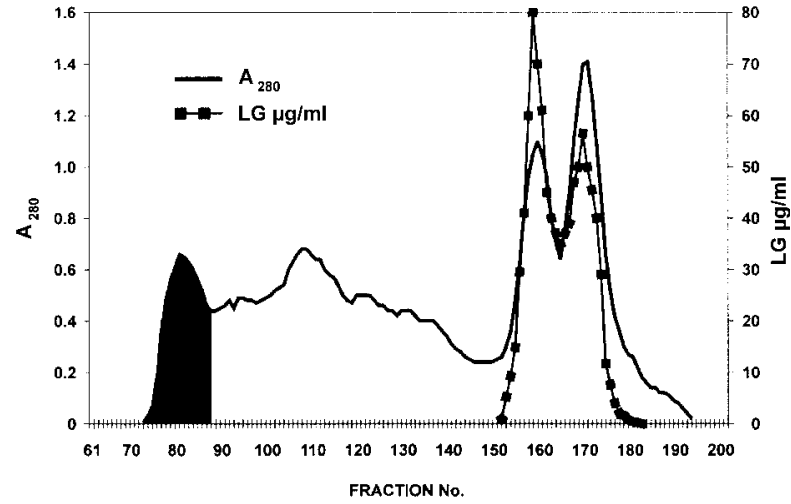

Figure 1 Chromatography on a column of Sephadex G-50 Superfine of the Gregory-Tracy hog antral gastrin extract equivalent to 800 antrums. The content of somatostatin and gastrin found by RIA in the individual lyophilized fractions of the effluent is shown in Table 1. The black peak corresponding to the content of tubes $72-87$ is normally regarded as the first discard fraction. Rabbit antisera to the lyophilized material of this fraction show strongly positive immunocytochemical reactions exclusively in the D cells of the GEP endocrine system, hence this material will be referred to as the deltin fraction and the antisera will be referred to as the antideltin sera. Gastrin heptadecapeptides I and II (LG='little gastrins' I and II) were found by RIA mainly in tubes 152-179 with the peak of gastrin II running ahead of the peak of gastrin I. The lyophilized material from these tubes was used for the isolation of LG I and LG II by two chromatographies on aminoethylcellulose using gradients of ammonium bicarbonate concentration described by Gregory \& Tracy (1964).

(62 ng/mg dry weight) by RIA (Table 1). The amino acid analysis of the material was performed by the method of Heinrikson \& Meredith (1984) after hydrolysis of samples in $6 \mathrm{~mol} / 1 \mathrm{HCl}$ in an HPLC apparatus from LKB (Bromma, Sweden). The analysis showed Glu and Asp as the principal amino acids of the deltin fraction. Absence of carbohydrate in the fraction was confirmed by the colorimetric method of Dubois et al. (1956) and by capillary

Table 1 Concentrations of somatostatin and gastrin found by RIA in the lyophilized material of the individual fractions obtained after gel filtration of the hog antral gastrin extract on Sephadex G-50 Superfine as shown in Fig. 1

Somatostatin (ng/mg dry weight)

\section{Fraction}

(tube nos)

$$
72-87
$$

88-103

104-120

$121-129$

130-142

$143-151$

$152-165$

$166-179$

\section{Gastrin}

(ng/mg dry weight)

62
52
57
122
433
55600
643000
398000

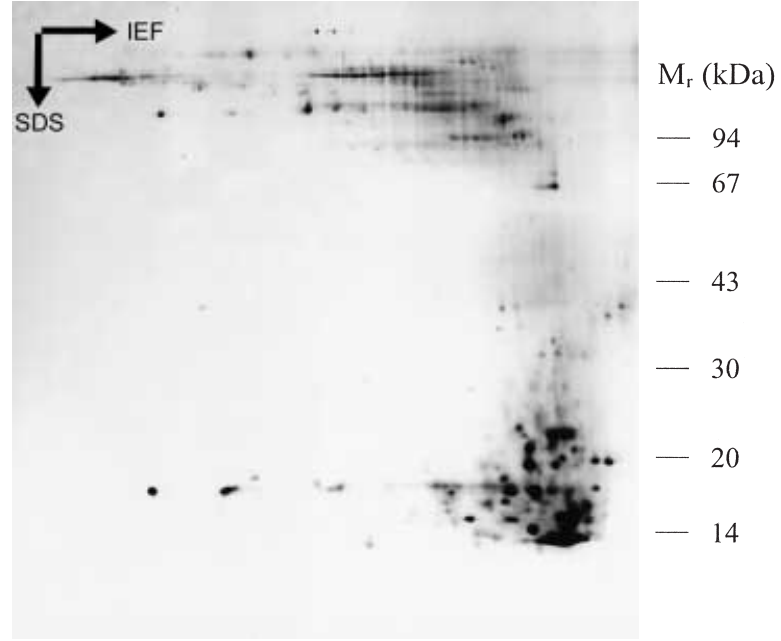

Figure 2 Two-dimensional PAGE of the lyophilized material obtained in the deltin fraction (see Fig. 1). The $\mathrm{pH}$ gradient runs from 3 at the right of the gel to 10 at the left. The pattern of this 2-D PAGE shows a marked heterogeneity of the material.

zone electrophoresis according to Honda et al. (1989) using the HPCE P/ACE System 2100 of Beckman (Fullerton, CA, USA).

\section{Antisera}

Antisera to somatostatin were prepared by immunization of four New Zealand rabbits and 20 albino rats with cyclic somatostatin-14 conjugated to BSA by the glutaraldehyde method (Arimura et al. 1975). The immunogen in PBS was emulsified with an equal volume of Freund's adjuvant. The rabbits received the emulsion injected subcutaneously into the hip region for 7 months at monthly intervals; the rats received a total of five subcutaneous immunizations. If used in immunocytochemistry or Western blotting, the rabbit and rat antisomatostatin antisera were absorbed by the addition of $1 \mathrm{mg}$ of BSA to $1 \mathrm{ml}$ of the undiluted antisera.

Antisera to porcine gastrin-17-I were prepared by immunizing successively a total of eight New Zealand rabbits with porcine gastrin-17-I obtained after the second chromatography on aminoethylcellulose (Gregory \& Tracy 1964). Prior to immunization, gastrin-17-I was coupled to BSA by the carbodiimide technique (Goodfriend et al. 1964). The solution of the conjugate in PBS was emulsified with an equal volume of Freund's adjuvant and the rabbits were immunized subcutaneously at intervals of 3-5 weeks for a total of seven to nine immunizations.

Antisera to the deltin fraction were prepared by immunizing five New Zealand rabbits with the lyophilized deltin fraction administered with the Al-Span-Oil adjuvant (Franěk \& Šimek 1971). Fifteen milligrams of the lyophilized material was dissolved in $3 \mathrm{ml}$ of PBS and mixed with $3 \mathrm{ml}$ of Willstätter's aluminium hydroxide suspension. The 
mixture was left in the refrigerator overnight. The suspension of the antigen was then emulsified with $9 \mathrm{ml}$ of the oil phase. The emulsified antigen was injected subcutaneously at monthly intervals for 6 months.

Antisera to human recombinant proinsulin were prepared by seven subcutaneous immunizations of six guinea pigs with human proinsulin in PBS, emulsified with Freund's adjuvant.

Pig antisera to rabbit immunoglobulin $G$ ( $\operatorname{Ig} G$ ) were prepared by immunizing three pigs subcutaneously with rabbit IgG that had been isolated from non-immune rabbit sera by protein A-Sepharose chromatography. The pigs received five immunizations at monthly intervals, the immunizing dose being $10 \mathrm{mg}$ of rabbit $\operatorname{IgG}$ in PBS emulsified with Freund's adjuvant per one pig per one immunization. Hog anti-rabbit IgG was isolated from the hog antiserum by protein A-Sepharose chromatography. Hog anti-rat IgG was obtained from Sevac. Hog antirabbit IgG was conjugated with FITC according to the method of The \& Feltkamp (1970). Hog anti-rat IgG was conjugated with HRP according to the periodate method (Wilson \& Nakane 1978) and with AMCA-NHS according to the instructions from Pierce. Protein A was conjugated with HRP using the periodate method.

\section{Radioimmunoassay of somatostatin and gastrin}

Radioiodination of $\left(\mathrm{Tyr}^{1}\right)$-somatostatin-14 and Tyrsomatostatin-28 was performed by the method of Patel (1984). After iodination the reaction mixture was purified on a column of Sephadex G-25 Fine $(1 \times 30 \mathrm{~cm})$ for labelled $\left(\mathrm{Tyr}^{1}\right)$-somatostatin-14 and on a column of Sephadex G-50 Superfine $(1 \times 60 \mathrm{~cm})$ for labelled Tyrsomatostatin-28. All four rabbit and 20 rat antisera to somatostatin-14 showed significant binding with the labelled Tyr-somatostatins. Radioimmunoassay of somatostatin was performed by the double antibody method. For the present study rabbit antiserum No. 733 was used, hog antiserum to rabbit $\operatorname{IgG}$ was used as the second antibody. Standard calibration curves were made from a stock solution of somatostatin-14. With antiserum 733 at final dilution of 1:20 000 the detection limit was 4 pg per tube, the intra-assay coefficient of variation was $8.6 \%$ and the inter-assay coefficient of variation was $11 \cdot 2 \%$. Rat antiserum No. 8 to somatostatin was used in immunocytochemical studies because of one of the lowest backgrounds.

Radioiodination of SHG I was performed by a modification of the method of Stadil \& Rehfeld (1972). After iodination, the reaction mixture was applied to a column of DEAE Sepharose Fast Flow $(1.5 \times 13.5 \mathrm{~cm})$ equilibrated with $50 \mathrm{mmol} / \mathrm{l}$ Tris- $\mathrm{HCl}, \mathrm{pH} 7 \cdot 8$, containing $200 \mathrm{mmol} / 1 \mathrm{NaCl}$. The reaction mixture was eluted by gradient elution at a flow rate of $60 \mathrm{ml} / \mathrm{h}$ using a linear gradient from the starting buffer $(100 \mathrm{ml})$ to $50 \mathrm{mmol} / \mathrm{l}$ Tris $-\mathrm{HCl}, \mathrm{pH} 7 \cdot 8$, containing $800 \mathrm{mmol} / 1 \mathrm{NaCl}$. The monoiodinated SHG I was eluted as a sharp symmetrical peak. Radioimmunoassay of gastrin was performed by the double antibody method using hog antiserum to rabbit $\mathrm{IgG}$ as the second antibody. All eight rabbit antisera to porcine gastrin-17-I showed significant binding with ${ }^{125}$ I-labelled SHG I. For the present study, rabbit antiserum No. 1 was used. Standard calibration curves were made from a stock solution of SHG I. With antiserum No. 1 at final dilution of 1:50 000 the detection limit was 5 pg per tube, the intra-assay coefficient of variation was $6 \cdot 1 \%$ and the inter-assay coefficient of variation was $8 \cdot 2 \%$.

\section{Isolation and extraction of canine pancreatic islets}

Outbred mongrel dogs weighing $8-18 \mathrm{~kg}$ were used as pancreas donors. Islet isolation was performed by the technique described by Ricordi et al. (1988). The islets were purified on a density gradient composed of four layers of Ficoll 400 DL with densities of $1 \cdot 125,1 \cdot 085$, 1.075 and 1.045 as described by Warnock et al. (1994). The islets were collected from the interface at 1.045/1.075 and 1.075/1.085 layers, washed in Hank's balanced salt solution (HBSS), counted, resuspended in Medium 199, rapidly frozen on dry ice and stored at $-196{ }^{\circ} \mathrm{C}$. The islet number harvested from individual dogs ranged from 20000 to 120000 .

The isolated islets removed from 17 dogs were boiled in $20 \mathrm{ml}$ of HPLC grade water for $5 \mathrm{~min}$, homogenized and boiled again for $30 \mathrm{~min}$. Following centrifugation the supernatant was saved and the sediment was homogenized and boiled in water for another $30 \mathrm{~min}$. The combined supernatants were lyophilized (aqueous extract). The sediment was stirred at room temperature in $20 \mathrm{ml}$ of $1 \mathrm{~mol} / \mathrm{l}$ acetic acid overnight. Following centrifugation the supernatant was lyophilized (acid extract).

\section{Immunocytochemistry}

Twenty-nine specimens of normal pancreatic tissue and 26 specimens of normal antroduodenal tissue were obtained at autopsy from persons without clinical evidence of pancreatic, gastrointestinal or endocrine disorder. A small aliquot of the isolated canine pancreatic islets was taken for immunocytochemistry, too. The tissues were fixed with neutral formalin, the aliquot of the isolated canine pancreatic islets was fixed in Bouin's fluid. After fixation, the tissues were embedded in paraffin. Sections of paraffinembedded tissue, $5 \mathrm{~mm}$ thick, were cut in a microtome and stained by the indirect immunofluorescent technique against deltins using rabbit antideltin antiserum 452 (diluted 1:64) for $2 \mathrm{~h}$ and FITC-conjugated hog antirabbit IgG. The sections were mounted in buffered glycerine and examined and photographed with the Olympus $\mathrm{BH}-2$ microscope. The sections were then washed in distilled water, refixed in Bouin's fluid and stained with a modification (Hellerström \& Hellman 1960) of the Davenport silver impregnation technique. 
The specificity of the antideltin immunofluorescence of the antral, duodenal and islet delta cells including sections of the isolated canine islets was checked by a series of specificity controls. Aliquots $(100 \mu \mathrm{l})$ of antideltin serum 452 at a dilution of 1:64 were absorbed with $100 \mu \mathrm{g}$ of the lyophilized deltin fraction, and with 100 and $300 \mu \mathrm{g}$ of each of the following peptides: cyclic somatostatin14, somatostatin-25, somatostatin-28, somatostatin-28 (1-12), somatostatin-28 (1-14), SHG I, highly purified porcine gastrin-17-I after the second chromatography on aminoethylcellulose, $\beta$-endorphin, met-enkephalin, leu-enkephalin.

The specificity of the antisomatostatin sera was tested by similar experiments: $100 \mu \mathrm{l}$ aliquots of appropriately diluted rabbit or rat antisomatostatins were absorbed with 50 or $100 \mu \mathrm{g}$ of cyclic somatostatin-14 and cross-absorbed with the lyophilized deltin fraction at concentrations of $100,300,500$ and $1000 \mu \mathrm{g}$ per $100 \mu \mathrm{l}$ of the diluted antiserum.

Double-label immunocytochemical staining was performed using first incubation of the pancreatic sections with rabbit antideltin antiserum and FITC-conjugated hog anti-rabbit IgG and then incubation with rat antisomatostatin antiserum and $\mathrm{HRP}$-conjugated hog anti-rat IgG followed by $\mathrm{H}_{2} \mathrm{O}_{2}$ and DAB. For double-label immunofluorescence the sections were first stained by the indirect immunofluorescent technique against deltins as above and then with the indirect immunofluorescent technique using rat antisomatostatin serum and AMCAconjugated hog anti-rat IgG. Prior to incubations, $1 \mathrm{ml}$ of FITC-conjugated hog anti-rabbit IgG was absorbed with $100 \mu \mathrm{l}$ of non-immune rat serum and aliquots of $1 \mathrm{ml}$ of HRP-conjugated hog anti-rat $\operatorname{IgG}$ and AMCA-conjugated hog anti-rat $\operatorname{IgG}$ were absorbed with $100 \mu \mathrm{l}$ of non-immune rabbit serum. Any immunologic cross-reactivity between the labelled immunoglobulins was excluded by incubating antroduodenal and pancreatic tissue sections first with rabbit antideltin serum and then with the absorbed HRP-conjugated or AMCAconjugated hog anti-rat IgG or, vice versa, by staining of the sections with rat antisomatostatin followed by the absorbed FITC-conjugated hog anti-rabbit IgG. No crossimmunoreactivity was observed on the sections stained with the absorbed labelled immunoglobulins.

For colour photographs of double immunofluorescence, filter cube BH2-DFC5 was used for the green immunofluorescence of FITC and filter cube BH2-DMU was employed for the blue immunofluorescence of AMCA. Colour photographs were taken using Ektachrome colour film (Kodak, Rochester, NY, USA).

\section{Two-dimensional electrophoresis (2-D PAGE)}

The lyophilized deltin fraction and the lyophilized aqueous and acid extracts of the isolated canine islets of Langerhans were dissolved in lysis buffer containing urea $(8 \mathrm{~mol} / \mathrm{l})$,
CHAPS (4\% w/v), Tris $(40 \mathrm{mmol} / \mathrm{l})$, DTT $(65 \mathrm{mmol} / \mathrm{l})$, Resolyte $\mathrm{pH} 4-8(2 \% \mathrm{v} / \mathrm{v})$ and a trace of bromophenol blue. Perfectly clear solutions were obtained. Samples equal to $100 \mu \mathrm{g}$ of the lyophilized materials were loaded on immobilized $\mathrm{pH}$ gradient strips, $\mathrm{pH} 3-10 \mathrm{NL}, 18 \mathrm{~cm}$, or $\mathrm{pH} 4-7$, for 2-D PAGE. Two-dimensional PAGE was performed according to Hochstrasser et al. (1988). Isoelectric focusing with immobilized sigmoid $\mathrm{pH} 3-10$ gradient and linear $\mathrm{pH} 4-7$ gradient was carried out in an Ultrophor apparatus (LKB) with a $5000 \mathrm{~V}$ power supply. The second dimension was performed in $9-16 \%$ polyacrylamide gradient gels using a Protean II xi 2-D Multi-Cell (Bio-Rad, Richmond, CA, USA). Proteins comprising the LMW electrophoresis calibration kit were run simultaneously. Protein and peptide spots were identified by ammoniacal silver staining.

\section{Western blot analysis}

Lysates of the aqueous and acid extracts of the isolated canine islets of Langerhans were separated by 2-D PAGE and transferred to Immobilon-P sheets in a Novablot Electrophoretic Transfer Kit (LKB). After the blocking, the blots were probed for either deltins by incubating with rabbit antideltin serum 452 (diluted 1:100), or somatostatins by incubating with rabbit antisomatostatin serum 733 (diluted 1:100), or proinsulins by incubating with guinea pig antiserum (diluted 1:150) against recombinant human proinsulin. Protein A-HRP was used as the second antibody, followed by $\mathrm{H}_{2} \mathrm{O}_{2}$ as substrate and DAB.

\section{Results}

Immunofluorescence studies showed that the antisera (diluted 1:50 to 1:100) from all five rabbits immunized with the lyophilized deltin fraction recognized a discrete population of cells in the antroduodenal mucosa and islets of Langerhans. These cells were identified as the D cells using the Hellerström-Hellman modification of the Davenport silver impregnation technique (Figs 3-5). It should be noted that despite the marked heterogeneity of the deltin fraction shown by 2-D PAGE (Fig. 2), all antideltin antisera stained exclusively the D cells of the GEP endocrine system. There were differences between the intensity of the immunofluorescence of the D cells in the pancreatic islets and in the antroduodenal mucosa, which may reflect the fact that all tissues had been fixed for different durations. Out of 29 specimens of the pancreas, the immunofluorescence of the $\mathrm{D}$ cells with the antideltin sera was strongly positive in 27 cases and intermediately positive in two cases. Out of 26 specimens of the antroduodenal mucosa, the antideltin immunofluorescence of the $\mathrm{D}$ cells was strongly positive in 19 cases, intermediately positive in seven cases and weakly positive in two cases. 

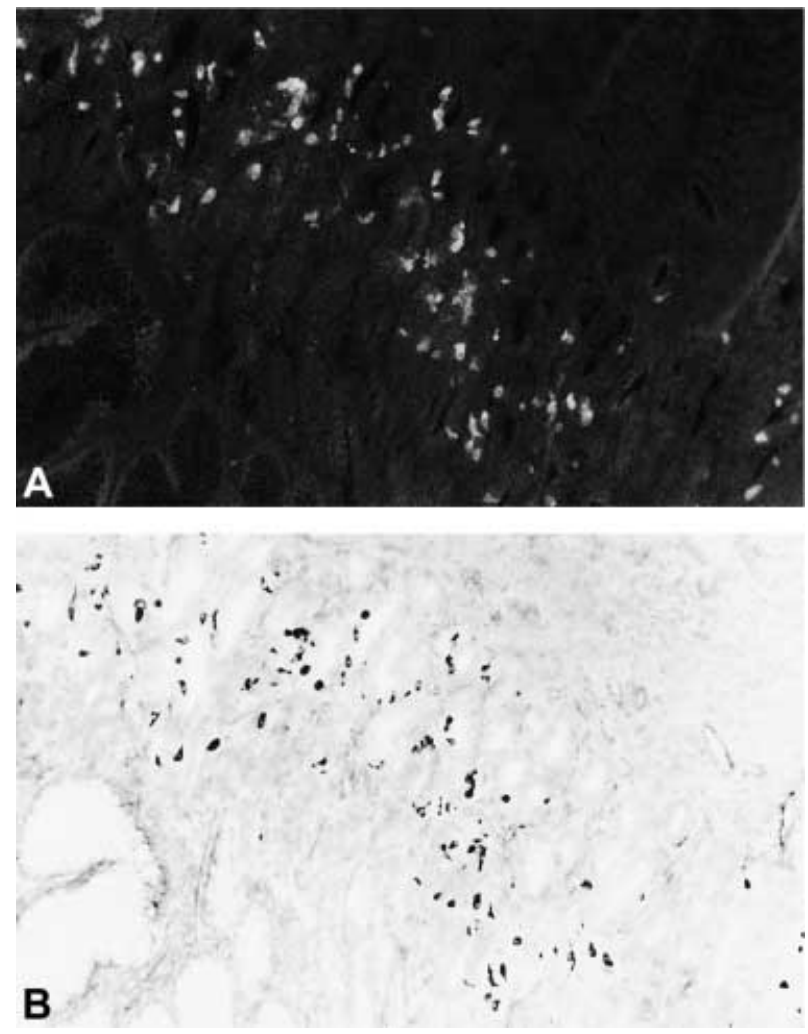

Figure 3 Fluorescence photomicrograph of the human antral pyloric mucosa stained by the indirect immunofluorescent technique against deltins using rabbit antideltin antiserum 452 and FITC-conjugated hog anti-rabbit IgG. The antideltin immunofluorescence is seen exclusively in a population of discrete cells (A). The same section and visual field as in (A) after refixation in Bouin's fluid and staining with the Hellerström-Hellman silver impregnation technique. The deltin-containing cells are seen to be identical with the silver-impregnated D cells (B). $\times 70$.

The specificity of the immunofluorescent reaction of the antideltin antisera in the $\mathrm{D}$ cells was confirmed by a series of specificity controls, notably by the absorption controls: (a) Absorption of diluted rabbit antideltin serum 452 with the lyophilized deltin fraction completely blocked the staining of the D cells of the GEP endocrine system by this antiserum. (b) Cross-absorption of the same antideltin serum with cyclic somatostatin-14, somatostatin-25, somatostatin 28 , somatostatin-28 (1-12), somatostatin-28 (1-14), SHG I, highly purified porcine gastrin-17-I after the second chromatography on AEcellulose, $\beta$-endorphin, met-enkephalin and leuenkephalin did not affect the staining of the D cells for deltins. (c) Absorption of the rabbit and rat appropriately diluted antisomatostatin antisera with cyclic somatostatin-14 completely blocked the staining of the D cells for somatostatin. (d) Cross-absorption of the rat and rabbit antisomatostatin antisera with the lyophilized deltin fraction failed to block the staining of the $\mathrm{D}$ cells for
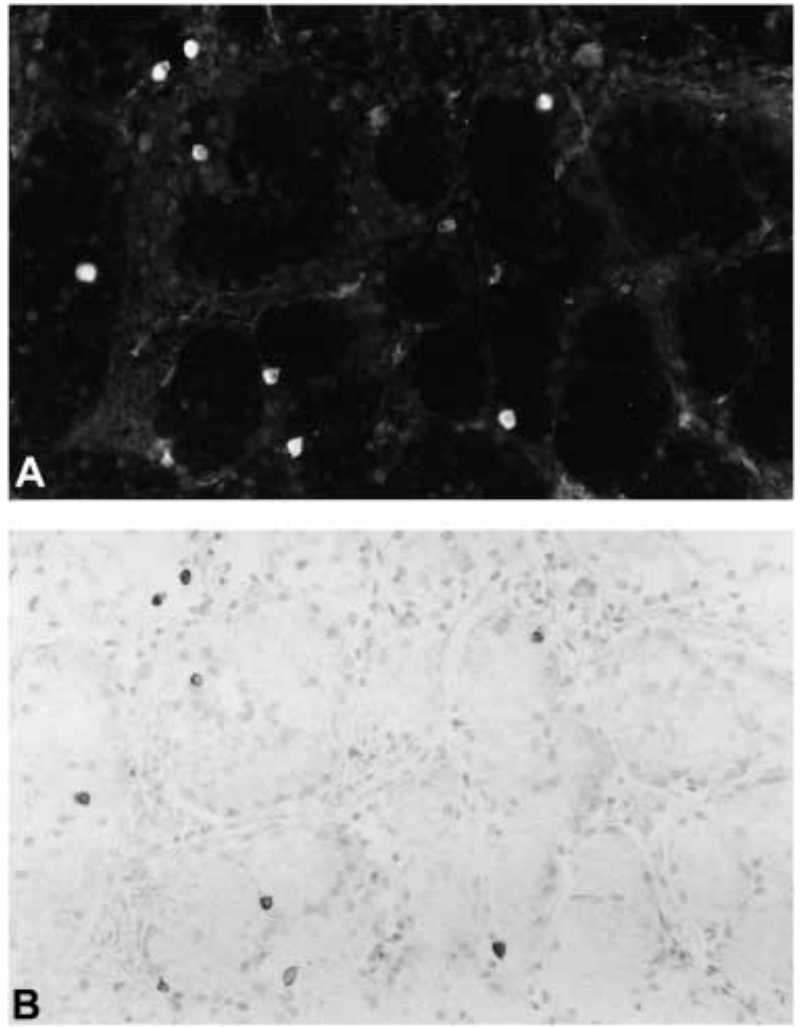

Figure 4 Fluorescence photomicrograph of the human duodenal mucosa stained by the indirect immunofluorescent technique against deltins. The antideltin immunofluorescence is seen exclusively in a population of discrete cells (A). The same section and visual field as in (A) after refixation in Bouin's fluid and staining with the Hellerström-Hellman silver impregnation technique. The deltin-containing cells are seen to be identical with the silver-impregnated D cells (B). $\times 140$.

somatostatin. These controls confirmed the specificity of the staining of the $\mathrm{D}$ cells for deltins.

In addition to immunocytochemical controls, the specificity of the antideltin antisera was checked also by RIA: none of the antideltin sera was found to bind radiolabelled $\left(\mathrm{Tyr}^{1}\right)$-somatostatin-14, Tyr-somatostatin-28 or SHG I.

Double-label immunocytochemical staining of the pancreatic islets combining the indirect immunofluorescent staining of deltins with the immunoperoxidase staining of somatostatin (Fig. 6) in the same islet showed a complete identity of the deltin-containing and somatostatin-containing cells. Similarly, double immunofluorescence combining the indirect immunofluorescent staining of deltins with rabbit antideltin serum and FITC-conjugated hog anti-rabbit $\operatorname{IgG}$ with the indirect immunofluorescent staining of somatostatin with rat antisomatostatin and AMCA-conjugated hog anti-rat IgG showed the identity of localization of the antideltin and antisomatostatin immunofluorescence in the same cells (Fig. 7) . 

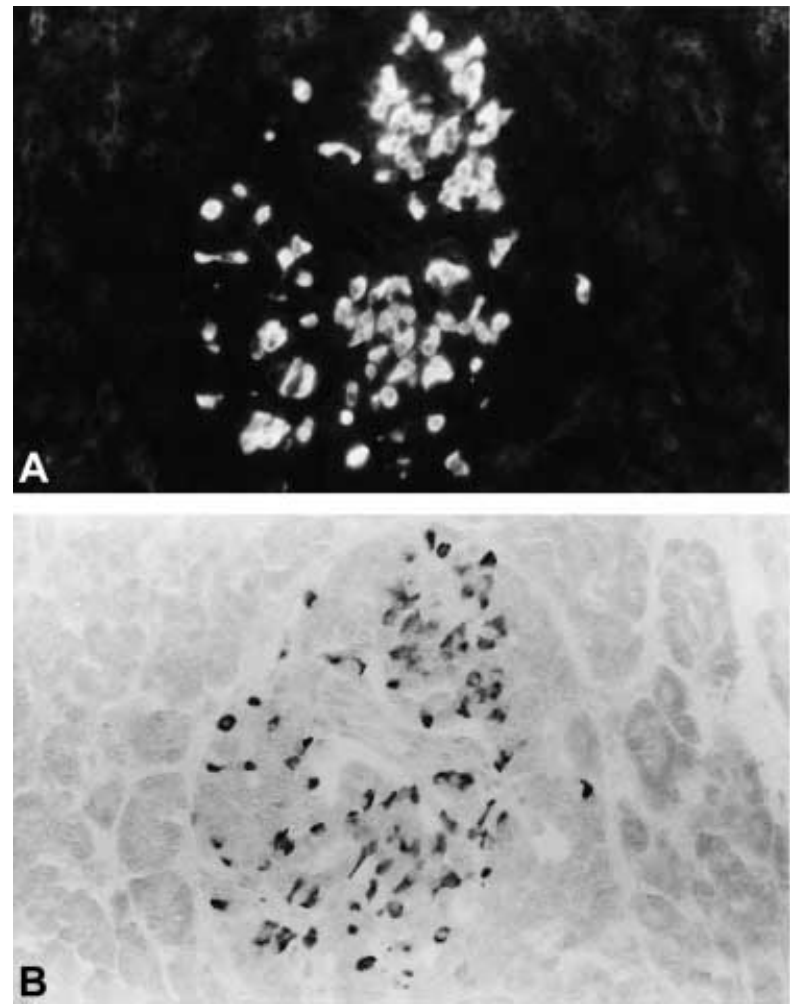

Figure 5 Fluorescence photomicrograph of a human islet stained by the indirect immunofluorescent technique against deltins. The antideltin immunofluorescence is seen exclusively in a population of discrete cells (A). The same section and visual field as in (A) after refixation in Bouin's fluid and staining with the Hellerström-Hellman silver impregnation technique. The deltin-containing cells are seen to be identical with the silver-impregnated D cells (B). × 140 .

It should be stressed that all of the eight antisera against the highly purified porcine gastrin-17-I after the second chromatography on aminoethylcellulose reacted immunocytochemically in formalin-fixed, paraffin-embedded tissues only with the $G$ cells and none of the antisera reacted with the D cells of the GEP endocrine system including the human pancreatic islets. These antisera therefore closely resembled the immunocytochemical behaviour of the antisera to SHG I (Lotstra et al. 1974).

The presence of scattered deltin cells in a section of the isolated canine islets of Langerhans was confirmed by the immunoperoxidase technique using antideltin 452 and protein A-HRP. Two-dimensional PAGE of the lyophilized aqueous extract of the isolated canine islets of Langerhans showed hundreds of spots. However, after the gel had been electroblotted to an Immobilon P membrane, 2-D Western blotting with the antideltin and antisomatostatin antisera showed only a few very faint spots. The main differences between the patterns of 2-D Western blots were found using the lyophilized acid extract of the
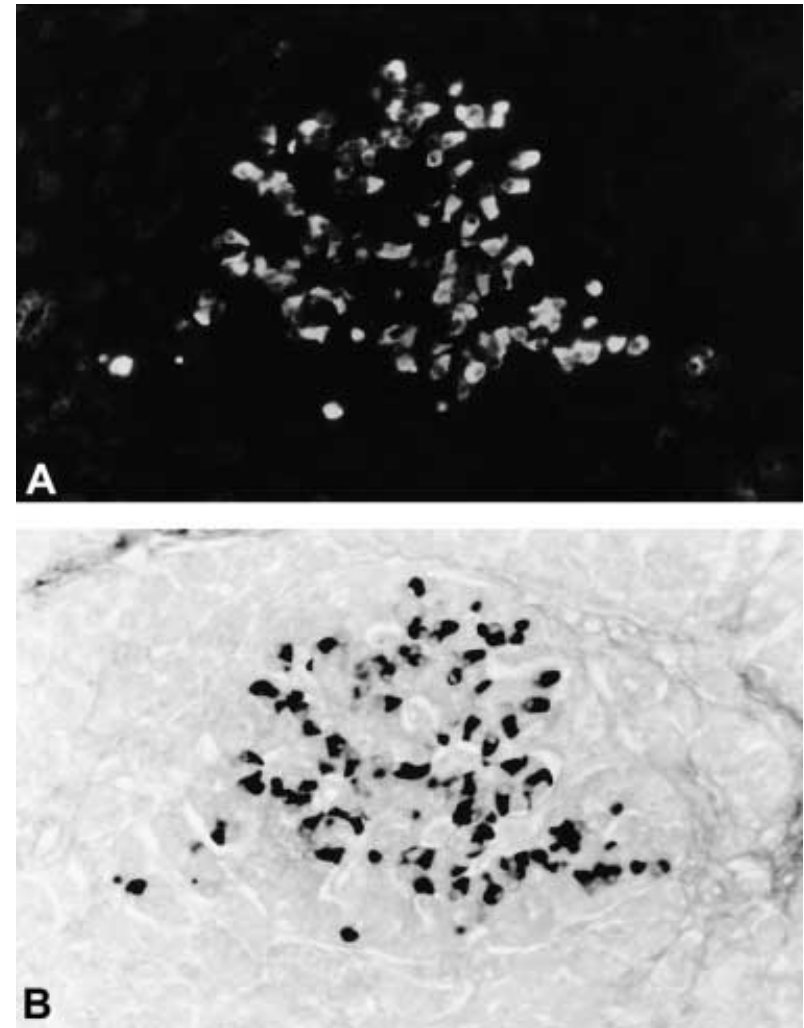

Figure 6 A human islet stained by double-label immunocytochemistry against deltins and somatostatin. After staining with rabbit antideltin antiserum 452 the section was stained with FITC-conjugated hog anti-rabbit IgG (A). The same section and islet after subsequent staining with rat antisomatostatin serum and HRP-conjugated hog anti-rat IgG using $\mathrm{H}_{2} \mathrm{O}_{2}$ as substrate and $\mathrm{DAB}$. The antideltin immunofluorescence is seen exclusively in cells that were identified subsequently by the immunoperoxidase technique to be somatostatin-containing cells (B). $\times 140$.

canine islets. Two-dimensional PAGE of the acid extract again showed a large number of spots (Fig. 8).

Two-dimensional Western blotting using the rabbit antideltin antiserum showed a distribution of immunoreactive spots (Fig. 9) that was quite different from the patterns of distribution of immunoreactive spots obtained with the antisomatostatin (Fig. 10) and antiproinsulin antisera (Fig. 11).

\section{Discussion}

In our study on the demonstration of gastrin in the $\mathrm{D}$ cells of the islets of Langerhans (Lomský et al. 1969) we used a rabbit antiserum to porcine gastrins I and II after chromatography of the antral gastrin extract on Sephadex-50 Superfine, which separates the peaks of both gastrins from each other. Additional chromatography of gastrins on AE-cellulose (Gregory \& Tracy 1964) was not regarded as 

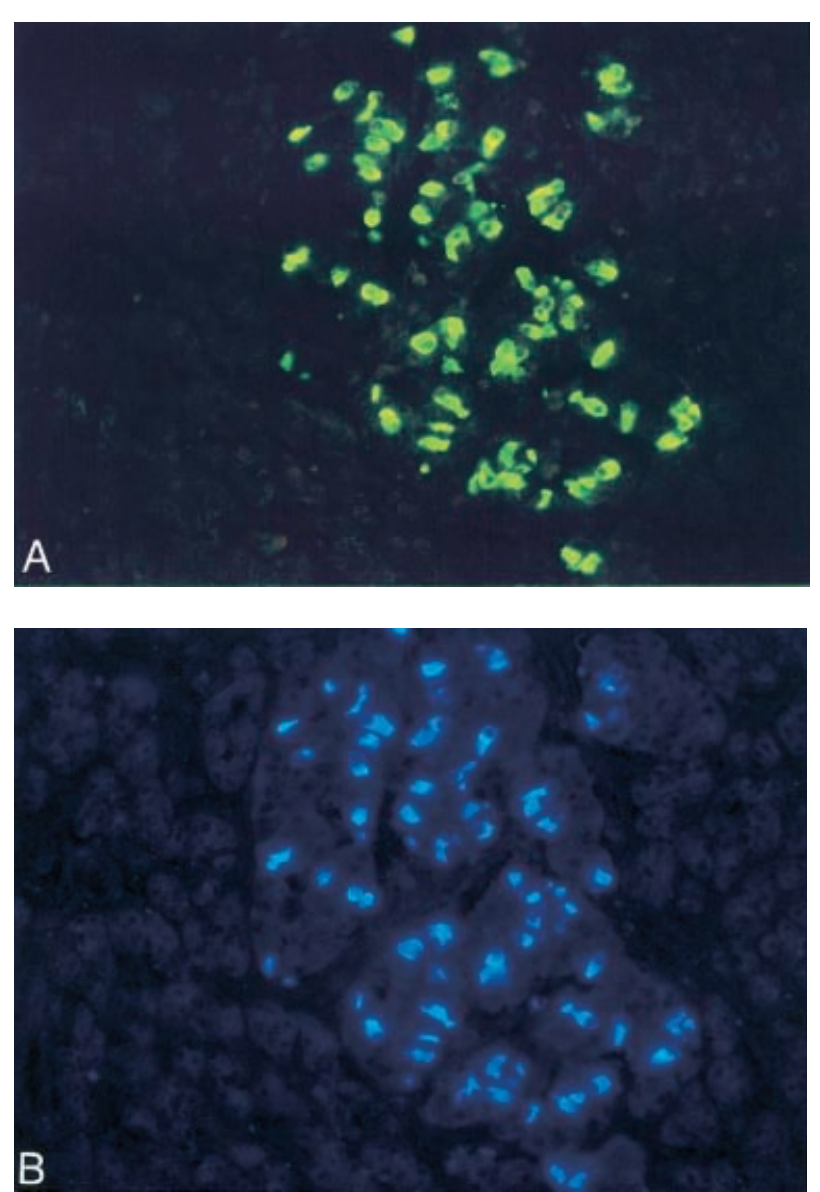

Figure 7 Fluorescence colour photomicrograph of a human islet stained by double immunofluorescence against deltins and somatostatin. The section was incubated with rabbit antideltin serum 452 followed by staining with FITC-conjugated hog anti-rabbit IgG. The deltin-containing cells display a yellow-green immunofluorescence (A). The same section and islet after subsequent staining with rat antisomatostatin serum and AMCA-conjugated hog anti-rat IgG (B). The somatostatincontaining cells show a blue immunofluorescence and are seen to be identical to the deltin-containing cells. $\times 140$.

necessary, since both gastrins were found to be potent stimulants of gastric acid secretion in a dog with a pouch of the gastric fundus and the possibility of an interference of other substances present in the gastrin preparations was not suspected. However, after we had incorporated the two chromatographies of the peaks of gastrin I and II on AE-cellulose into the purification of gastrins with only the middle portions of the gastrin peaks collected for lyophilization, we obtained successively eight antisera to porcine gastrin-17-I that closely resemble the immunocytochemical behaviour of antisera to SHG I (Lotstra et al. 1974) in that they give, in formaldehyde-fixed, paraffin-embedded tissues, positive reactions in the $G$ cells of the GEP endocrine system (Lomský et al. 1972) according to the

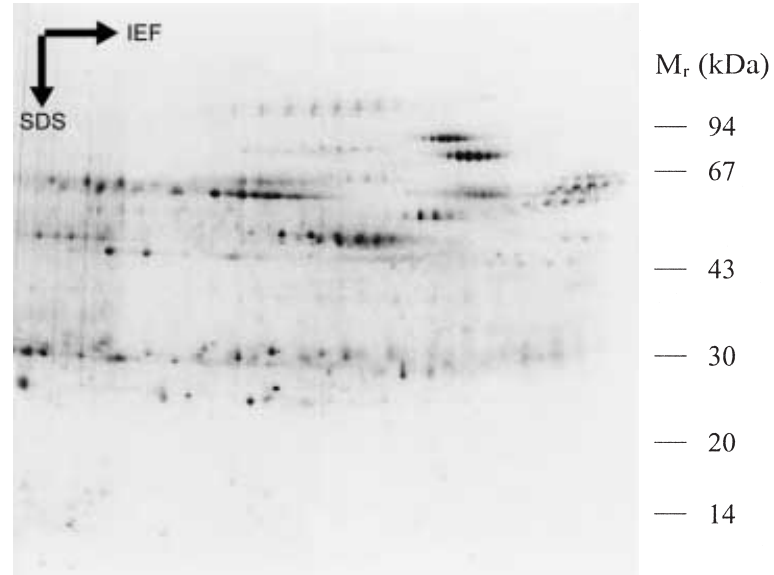

Figure 8 Two-dimensional PAGE of the acid extract of the isolated canine islets of Langerhans. The $\mathrm{pH}$ gradient runs from 4 at the right of the gel to 7 at the left.

terminology presented at the Wiesbaden Symposium on gastrointestinal hormones (Forssmann 1970) and in that they give negative reactions in the Davenport positive D cells (Kubeš et al. 1974). Similar immunocytochemical findings were obtained by Erlandsen et al. (1976). These authors used commercial high affinity guinea pig antisera to porcine gastrin prepared from antral mucosa and

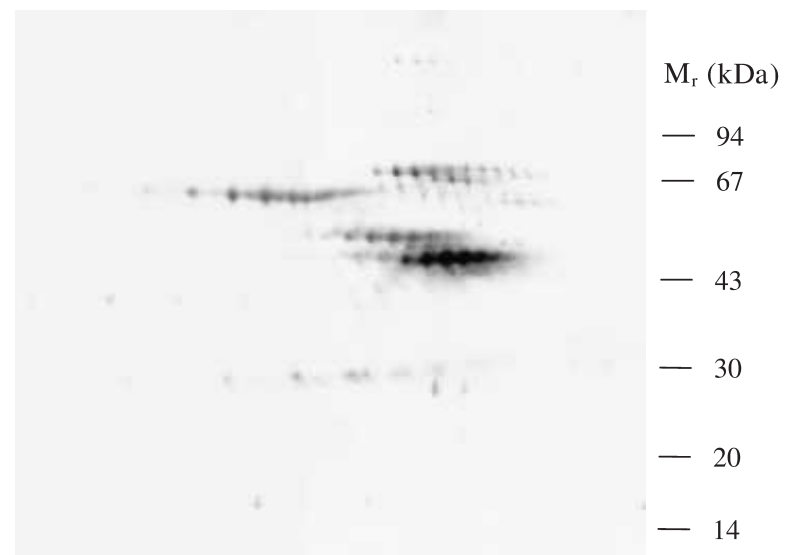

Figure 9 Two-dimensional Western blot of canine deltins in the acid extract of the canine pancreatic islet. Peptides were separated by 2-D PAGE as shown in Fig. 8 and the gel was electroblotted to an Immobilon-P membrane. The detection was performed with rabbit antideltin serum 452 (diluted 1:100) and protein A-HRP (diluted 1:100) using $\mathrm{H}_{2} \mathrm{O}_{2}$ as substrate and DAB. Note the difference between the pattern of distribution of the immunoreactive deltin spots as compared with the patterns of immunoreactive spots obtained on 2-D Western blots with the antisomatostatin (Fig. 10) and antiproinsulin antisera respectively (Fig. 11). 


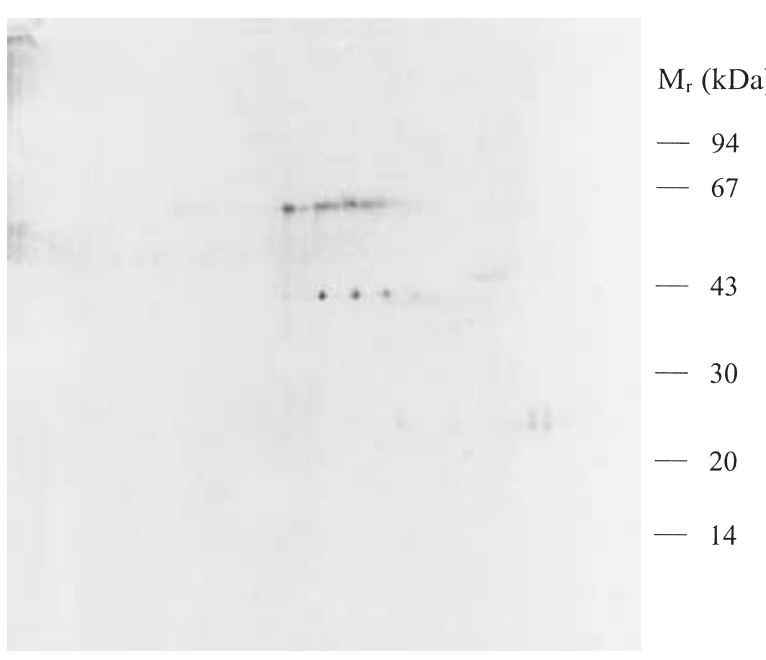

Figure 10 Two-dimensional Western blot of immunoreactive spots in the acid extract of the canine islets after staining with rabbit antisomatostatin serum 733 (diluted 1:100) and protein A-HRP (diluted 1:100) using $\mathrm{H}_{2} \mathrm{O}_{2}$ as substrate and DAB. Peptides were separated by 2-D PAGE as shown in Fig. 8 and the gel was electroblotted to an Immobilon-P membrane.

obtained positive reactions in the $\mathrm{D}$ cells of the human islets in Bouin-fixed sections of the pancreas. Absorption of the antisera with porcine gastrin obtained from another commercial company completely blocked the staining of the D cells. However, staining of the islets with commercial rabbit antisera to synthetic human gastrins I and II was negative.

The above results suggested the existence in hog antral gastrin extracts of peptides different from gastrin that are

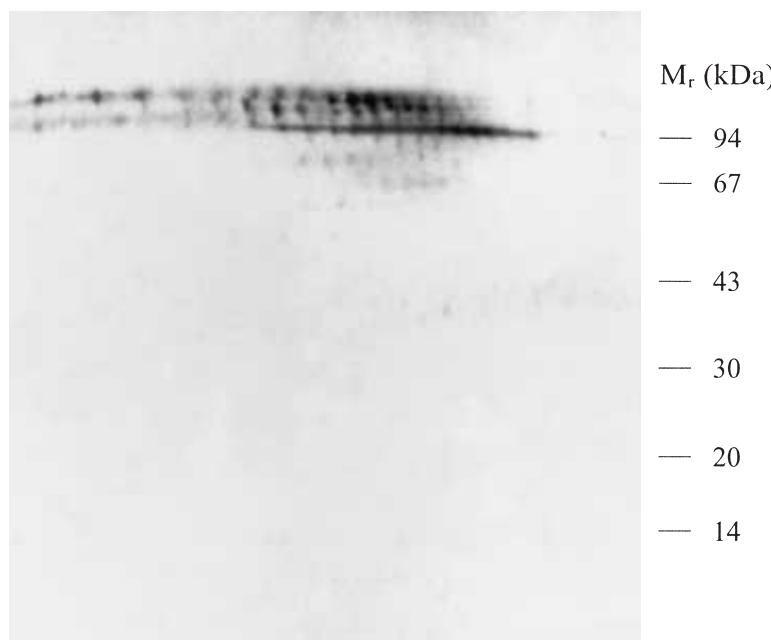

Figure 11 Two-dimensional Western blot of immunoreactive spots in the acid extract of the canine islets after staining with a guinea pig antiserum to human proinsulin (diluted 1:150) and protein A-HRP (diluted 1:100) using $\mathrm{H}_{2} \mathrm{O}_{2}$ as substrate and DAB. Peptides were separated by 2-D PAGE as shown in Fig. 8 and the gel was electroblotted to an Immobilon-P membrane. responsible for the immunocytochemical reaction of the anti-porcine gastrin antisera in the D cells of the GEP endocrine system. This study presents evidence of the presence of such peptides in the Gregory-Tracy hog antral gastrin extracts. Five rabbit antisera to the first discard fraction after gel filtration of the antral gastrin extracts on Sephadex G-50 Superfine, which contains only traces of somatostatin and gastrin in RIA, stain exclusively the D cells of the GEP endocrine system, the staining of the D cells is abolished after absorption of the antisera with the homologous antigen but not with somatostatin-14 and a number of other peptides. These antisera do not bind labelled $\left(\mathrm{Tyr}^{1}{ }^{1}\right)$-somatostatin-14, Tyr-somatostatin-28 or labelled SHG I. The staining of the D cells with the antisomatostatins is abolished by absorption of the sera with somatostatin, but not with excess of the deltin fraction. In addition, 2-D maps of immunoreactive spots obtained after staining of Western blots of acid extracts of isolated canine islets with antideltin, antisomatostatin and antiproinsulin sera show different patterns. For all these reasons it seems justified to separate this population of peptides from the populations of somatostatins and gastrins and to propose the term deltins for their designation because of their origin in the $\mathrm{D}$ (delta) cells of the GEP endocrine system. Work on the isolation and characterization of individual deltins is under way.

\section{Acknowledgements}

This work was supported in part by grant no. 3695-3 of the Internal Grant Agency of the Ministry of Health and by grant no. 3 08/96/1514 of the Grant Agency of the Czech Republic. Dr F Langr of the Fingerland Institute of Pathology kindly supplied the autopsy specimens of the antroduodenal and pancreatic tissue. The technical assistance of O Koblížková, V Čiháková, E Číhalová, and $\mathrm{J}$ Špundová is gratefully acknowledged.

\section{References}

Alumets J, Sundler F \& Håkanson R 1977 Distribution, ontogeny and ultrastructure of somatostatin immunoreactive cells in the pancreas and gut. Cell and Tissue Research 185 465-479.

Arimura A, Sato H, Coy DH \& Schally AV 1975 Radioimmunoassay for GH-release inhibiting hormone. Proceedings of the Society for Experimental Biology and Medicine 148 784-789.

Braaten JT, Schenk A, Lee MJ, McGuigan JE \& Mintz DH 1974 Cyclic nucleotide-mediated secretion of glucagon and gastrin in monolayer culture of rat pancreas. Journal of Clinical Investigation $\mathbf{5 3}$ 10a.

Braaten JT, Greider MH, McGuigan JE \& Mintz DH 1976 Gastrin in the perinatal rat pancreas and gastric antrum: immunofluorescence localization of pancreatic gastrin cells and gastrin secretion in monolayer cells cultures. Endocrinology 99 684-691.

Brazeau P, Vale W, Burgus R, Ling N, Butcher M, Rivier J \& Guillemin R 1973 Hypothalamic polypeptide that inhibits the secretion of immunoreactive pituitary growth hormone. Science 179 $77-79$. 
Creutzfeldt W 1975 Pancreatic endocrine tumors - the riddle of their origin and hormone secretion. Israel Journal of Medical Sciences 11 762-776.

Creutzfeldt W, Arnold R, Creutzfeldt C, Feurle G \& Ketterer H 1971 Gastrin and G-cells in the antral mucosa of patients with pernicious anaemia, acromegaly and hyperparathyroidism and in a Zollinger-Ellison tumour of the pancreas. European Journal of Clinical Investigation 1 461-479.

Dockray GJ, Best L \& Taylor IL 1977 Immunochemical characterization of gastrin in pancreatic islets of normal and genetically obese mice. Journal of Endocrinology 72 143-151.

Dubois MP 1975 Presence of immunoreactive somatostatin in discrete cells of the endocrine pancreas. PNAS 72 1340-1343.

Dubois M, Gilles KA, Hamilton JK, Rebers PA \& Smith F 1956 Colorimetric method for determination of sugars and related substances. Analytical Chemistry 28 350-356.

Erlandsen SL, Hegre OD, Parsons JA, McEvoy RC \& Elde RP 1976 Pancreatic islet cell hormones. Distribution of cell types in the islet and evidence for the presence of somatostatin and gastrin within the D cell. Journal of Histochemistry and Cytochemistry 24 883-897.

Forssmann WG 1970 Ultrastructure of hormone-producing cells of the upper gastrointestinal tract. In Origin, Chemistry, Physiology and Pathophysiology of the Gastrointestinal Hormones. International Symposium, Wiesbaden, 24 and 25 October 1969, pp 31-70. Eds W Creutzfeldt, RA Gregory, MI Grossman \& AGE Pearse. Stuttgart: Schattauer Verlag.

Franěk F \& Šimek L 1971 The antibody response of pigs to dinitrophenylated bovine $\operatorname{IgG}$ administered with a novel type of adjuvant. European Journal of Immunology 1 300-302.

Goodfriend TL, Levine L \& Fasman GD 1964 Antibodies to bradykinin and angiotensin: a use of carbodiimides in immunology. Science 144 1344-1346.

Gregory RA \& Tracy HJ 1964 The constitution and properties of two gastrins extracted from hog antral mucosa. Gut 5 103-114.

Greider MH \& McGuigan JE 1971 Cellular localization of gastrin in the human pancreas. Diabetes 20 389-396.

Heinrikson RL \& Meredith SC 1984 Amino acid analysis by reversephase high-performance liquid chromatography: precolumn derivatization with phenylisothiocyanate. Analytical Biochemistry 136 65-74.

Hellerström C \& Hellman B 1960 Some aspects of silver impregnation of the islets of Langerhans in the rat. Acta Endocrinologica 35 $518-532$.

Hochstrasser DF, Harrington MG, Hochstrasser AC, Miller MJ \& Merril CR 1988 Methods for increasing the resolution of two-dimensional protein electrophoresis. Analytical Biochemistry 173 424-435.

Hökfelt T, Efendić S, Hellerström C, Johansson O, Luft R \& Arimura A 1975 Cellular localization of somatostatin in endocrine-like cells and neurons of the rat with special reference to the $A_{1}$-cells of the pancreatic islets and to the hypothalamus. Acta Endocrinologica $\mathbf{8 0}$ (Suppl 200) 1-41.

Honda S, Iwase S, Makino A \& Fujiwara S 1989 Simultaneous determination of reducing monosaccharides by capillary zone electrophoresis as the borate complexes of N-2-pyridylglycamines. Analytical Biochemistry 176 72-77.

Kubeš L, Jirásek K \& Lomský R 1974 Endocrine cells of the dog gastrointestinal mucosa. Cytologia 39 179-194.

Larsson LI, Håkanson R, Sjöberg \& Sundler F 1975 Fluorescence histochemistry of the gastrin cell in fetal and adult man. Gastroenterology 68 1152-1159.
Larsson LI, Rehfeld JF, Sundler F \& Håkanson R 1976 Pancreatic gastrin in foetal and neonatal rats. Nature 262 609-610.

Lomský R, Langr F \& Vortel V 1969 Immunohistochemical demonstration of gastrin in mammalian islets of Langerhans. Nature 223 618-619.

Lomský R, Kubeš L \& Jirásek K 1972 Intracellular localization of gastrin in the canine antral mucosa by the immunoenzyme technique. Sborník Védeckých Prací Lékařské Fakulty Univerzity Karlovy 15 571-576.

Lotstra F, van der Loo W \& Gepts W 1974 Are gastrin-cells present in mammalian pancreatic islets? Diabetologia 10 291-302.

Luft R, Efendić S, Hökfelt T, Johansson O \& Arimura A 1974 Immunohistochemical evidence for the localization of somatostatinlike immunoreactivity in a cell population of the pancreatic islets. Medical Biology 52 428-430.

Nilsson G, Yalow RS \& Berson SA 1973 Distribution of gastrin in the gastrointestinal tract of human, dog, cat and hog. In Frontiers in Gastrointestinal Hormone Research, pp 95-101. Ed. S Andersson. Stockholm: Almqvist \& Wiksell.

Orci L, Baetens D, Dubois MP \& Rufener C 1975 Evidence for the $\mathrm{D}$-cell of the pancreas secreting somatostatin. Hormone and Metabolic Research 7 400-402.

Patel YC 1984 Radioimmunoassay of somatostatin-related peptides. In Diabetic Research, Volume I: Laboratory Methods, Part B, pp 307-327. Eds J Larner \& SL Pohl. New York: Wiley.

Polak JM, Stagg B \& Pearse AGE 1972 Two types of ZollingerEllison syndrome: immunofluorescent, cytochemical and ultrastructural studies of the antral and pancreatic gastrin cells in different clinical states. Gut 13 501-512.

Polak JM, Pearse AGE, Grimelius L, Bloom SR \& Arimura A 1975 Growth-hormone release-inhibiting hormone in gastrointestinal and pancreatic D-cells. Lancet i 1220-1222.

Ricordi C, Lacy PE, Finke EH, Olack BJ \& Scharp DW 1988 Automated method for isolation of human pancreatic islets. Diabetes 37 413-420.

Rufener C, Dubois MP, Malaisse-Lague F \& Orci L 1975 Immunofluorescent reactivity to anti-somatostatin in the gastro-intestinal mucosa of the dog. Diabetologia 11 321-324.

Stadil F \& Rehfeld JF 1972 Preparation of ${ }^{125}$ I-labeled synthetic human gastrin I for radioimmunoanalysis. Scandinavian Journal of Clinical and Laboratory Investigation 30 361-368.

The TH \& Feltkamp TEW 1970 Conjugation of fluorescein isothiocyanate to antibodies. II. A reproducible method. Immunology 18 875-881.

Vassallo G, Solcia E, Bussolati G, Polak JM \& Pearse AGE 1972 Non-G cell gastrin-producing tumours of the pancreas. Virchows Archiv. B. Cell Pathology 11 66-79.

Warnock GL, Ao Z, Lakey JRT \& Rajone RV 1994 Islet isolation from canine pancreas. In Pancreatic Islet Transplantation, vol I. Procurement of Pancreatic Islets, pp 81-95. Eds RP Lanza \& WL Chick. Austin: R G Landes Co.

Wilson MB \& Nakane PK 1978 Recent developments in the periodate method of conjugating horseradish peroxidase (HRPO) to antibodies. In Immunofluorescence and Related Staining Techniques, pp 215-224. Eds W Knapp, K Holubar \& G Wick. Amsterdam: Elsevier/North Holland.

Received 30 August 2000

Accepted 3 November 2000 